\title{
Reduced Rearing Temperature Augments Responses in Sympathetic Outflow to Brown Adipose Tissue
}

\author{
Shaun F. Morrison, ${ }^{1}$ Sheela Ramamurthy, ${ }^{1}$ and James B. Young ${ }^{2}$ \\ Departments of ${ }^{1}$ Physiology and ${ }^{2}$ Medicine, Northwestern University Medical School, Chicago, Illinois 60611
}

\begin{abstract}
Sympathetic outflow to brown adipose tissue (BAT) contributes to both thermoregulation and energy expenditure in rats through regulation of BAT thermogenesis. Acute cold exposure in mature animals augments BAT thermogenesis; however, the enhanced BAT thermogenic response returns to normal shortly after cessation of the cold exposure. In this study, we sought to determine whether cold exposure in early neonatal life could induce enhanced responses in the sympathetic outflow to BAT and whether this altered sympathetic regulation would be sustained after the cold stimulus was removed. BAT sympathetic nerve activity (SNA) was recorded in urethane-chloraloseanesthetized, artificially ventilated rats that were raised from birth in either 18 or $30^{\circ} \mathrm{C}$ environments and then, at 8 weeks of age, were maintained in $23^{\circ} \mathrm{C}$ for at least 4 weeks. An acute hypothermic stimulus, disinhibition of a brainstem thermogenic net-
\end{abstract}

work in the raphe pallidus, or electrical stimulation in this raphe site produced increases in BAT SNA that were twice as great in rats reared at $18^{\circ} \mathrm{C}$ as in those reared at $30^{\circ} \mathrm{C}$. The norepinephrine content of the interscapular BAT (IBAT) and the number of sympathetic ganglion cells projecting to interscapular BAT were $70 \%$ greater in the $18^{\circ} \mathrm{C}$-reared rats. We conclude that neonatal exposure to a cold environment induces a permanent developmental alteration in the capacity for sympathetic stimulation of BAT thermogenesis that may be mediated, in part, by a greater number of sympathetic ganglion cells innervating BAT in coldreared animals.

Key words: raphe pallidus; sympathetic ganglion; sympathetic development; brown adipose tissue; thermogenesis; cold acclimation; bicuculline; fast blue
Development within the mammalian nervous system continues well after birth. Consequently, postnatal sensory experiences exert a formative influence on the maturation of numerous components of the nervous system, including visual and auditory pathways (Hubel and Wiesel, 1970; Moore, 1985; Thoenen, 1995), the somatosensory and olfactory systems (Woolsey et al., 1981; Brunjes and Frazier, 1986), and the networks controlling respiration (Ling et al., 1997; Erickson et al., 1998). The finding that alterations in early postnatal environment can result in changes in nervous system function that are maintained throughout life has lead to the concept of developmental plasticity in which altered levels of growth factors or other signaling molecules resulting from exposure to environmental factors can affect cell number (perhaps through influences on the apoptotic process) or function in the nervous system to produce permanent alterations in behavior or organ function. The present study was designed to determine whether a similar developmental plasticity could influence thermoregulatory responses in adult animals. Specifically, we tested the hypothesis that a reduction in neonatal rearing temperature would result in a sustained amplification of the thermogenic responses in brown adipose tissue (BAT) that are known to play a critical role in heat production during acute cold exposure in normal (Foster, 1984) and in cold-acclimated (Foster and Frydman, 1979) rats.

Cold acclimation, produced by repeated cold stress in adult animals, leads to a greater cold tolerance and an augmented metabolic heat production in subsequent cold challenges (LeBlanc et al., 1967; Talan and Engel, 1988). Both a centrally mediated enhancement of the level of sympathetic outflow to BAT (Kawate et al., 1994) and an upregulation of BAT metabolic processes contribute to these enhanced thermogenic responses. The amplified BAT thermogenesis in cold acclimation is lost, however, if the interval between cold exposures is increased from 2 to 4 weeks (Talan and Engel, 1988), indicating a return to normal conditions in the ab-

\footnotetext{
Received July 14, 2000; revised Sept. 14, 2000; accepted Sept. 26, 2000.

This research was supported by National Institutes of Health Grant DK-20378.

Correspondence should be addressed to Dr. Shaun F. Morrison, Department of Physiology (M211), Northwestern University Medical School, 303 E. Chicago Avenue, Chicago, IL 60611. E-mail: s-morrison2@northwestern.edu.

Copyright (C) 2000 Society for Neuroscience $0270-6474 / 00 / 209264-08 \$ 15.00 / 0$
}

sence of the conditioning cold stimulus. It has not been determined whether neonatal cold exposure can induce alterations in the control of BAT sympathetic nerve activity (SNA) that are similar to those seen in cold acclimation, but are sustained on the return to a normothermic environment.

Although the hypothalamus plays a critical role in the initiation and control of various processes that increase BAT metabolic activity, including the thermogenic response to environmental cold (Boulant, 1980), the pathway(s) by which changes in hypothalamic neuronal discharge influence the sympathetic preganglionic neurons controlling BAT remain largely unknown. Recently, we have discovered a potential role for neurons in the rostral medullary raphe nuclei, including raphe pallidus $(\mathrm{RPa})$, in the central thermogenic network regulating BAT SNA (Morrison et al., 1999). This information has provided the unique opportunity to determine the effect of altering neonatal environmental temperature on the responses resulting from activation of neurons in the brainstem circuits driving BAT thermogenesis.

A preliminary report of these results has been published previously (Morrison and Young, 1998).

\section{MATERIALS AND METHODS}

Animals. One-day-old male and female Sprague Dawley rats with multiparous foster mothers were obtained from Charles River Breeding Laboratories (Wilmington, MA). On arrival, litters were culled to 10 pups, and each litter with foster mother was placed in a standard plastic cage (length, $18.5 \mathrm{in}$; width, $10 \mathrm{in}$; height, 8 in) lined with wood shavings. Cages were then placed in one of two temperature-controlled chambers set at 18 or $30^{\circ} \mathrm{C}\left( \pm 0.2^{\circ} \mathrm{C}\right)$. Because the cages were covered only by wire grids, the temperatures in the cages were similar to the internal temperatures of the chambers. The chambers (Model ST50 GC/M; Sure-Temp, Apex, NC; internal volume, $50 \mathrm{ft}^{3}$ ) were equipped with glass doors, and illumination was provided by room lighting as well as by a timer-controlled internal light set to coincide with the $14 / 10 \mathrm{hr}$ light/dark cycle of the room. Litters and mothers were left undisturbed, except for weekly cage changes. Pups were weaned at 21-22 d, removed from the chambers at $60 \mathrm{~d}$ of age, and housed in a room at $21 \pm 0.2^{\circ} \mathrm{C}$ for at least $30 \mathrm{~d}$ until participation in the acute experiments described below. Rats were provided ad libitum access to water and standard laboratory chow (Prolab R-M-H 3000; Agway, Syracuse, NY). The animals used in this study were maintained in accordance with the guidelines and approval of the Animal Care and Use Committee of Northwestern University.

Neural recordings and stimulations. Rats were anesthetized intravenously 
Table 1. Cardiovascular variables in rats reared at $18^{\circ} \mathrm{C}$ and $30^{\circ} \mathrm{C}$ and changes evoked by acute hypothermia and disinhibition of raphe pallidus neurons

Control Acute hypothermia

\begin{tabular}{|c|c|c|c|c|c|c|c|c|c|}
\hline \multirow[b]{2}{*}{$\begin{array}{l}\text { Rearing } \\
\text { temperature }\end{array}$} & & & \\
\hline & $\begin{array}{l}\text { MAP } \\
(\mathrm{mmHg})\end{array}$ & $\begin{array}{l}\mathrm{PP} \\
(\mathrm{mmHg})\end{array}$ & $\begin{array}{l}\text { HR } \\
(\mathrm{bpm})\end{array}$ & $\begin{array}{l}\Delta \mathrm{MAP} \\
(\mathrm{mmHg})\end{array}$ & $\begin{array}{l}\Delta \mathrm{PP} \\
(\mathrm{mmHg})\end{array}$ & $\begin{array}{l}\Delta \mathrm{HR} \\
(\mathrm{bpm})\end{array}$ & $\begin{array}{l}\Delta \mathrm{MAP} \\
(\mathrm{mmHg})\end{array}$ & $\begin{array}{l}\Delta \mathrm{PP} \\
(\mathrm{mmHg})\end{array}$ & $\begin{array}{l}\Delta \mathrm{HR} \\
(\mathrm{bpm})\end{array}$ \\
\hline $18^{\circ} \mathrm{C}$ & $108 \pm 4$ & $59 \pm 2$ & $345 \pm 8$ & $+11 \pm 3$ & $+9 \pm 2$ & $+41 \pm 7$ & $+18 \pm 3$ & $+12 \pm 2^{*}$ & $+70 \pm 7$ \\
\hline $30^{\circ} \mathrm{C}$ & $106 \pm 4$ & $57 \pm 4$ & $357 \pm 7$ & $+11 \pm 4$ & $+14 \pm 3$ & $+55 \pm 9$ & $+22 \pm 4$ & $+23 \pm 5$ & $+84 \pm 14$ \\
\hline
\end{tabular}

$M A P$, Mean arterial pressure; $P P$, pulse pressure; $H R$, heart rate; $\Delta$, evoked change; $B I C$, bicuculline; $R P a$, raphe pallidus.

*Significant difference $(p<0.05)$ between $18^{\circ} \mathrm{C}$ - and $30^{\circ} \mathrm{C}$-reared rats.

with urethane $(0.8 \mathrm{gm} / \mathrm{kg})$ and chloralose $(80 \mathrm{mg} / \mathrm{kg})$ after induction with $3 \%$ isoflurane in $100 \% \mathrm{O}_{2}$. A femoral artery, a femoral vein, and the trachea were cannulated for measurement of arterial pressure, drug injection, and artificial ventilation, respectively. Heart rate was determined from the arterial pressure signal. Animals were positioned prone in a stereotaxic frame (incisor bar, $-11.0 \mathrm{~mm}$ ) with a spinal clamp on the T10 vertebra, paralyzed with D-tubocurarine $(0.3 \mathrm{mg}$ initial dose, $0.1 \mathrm{mg} / \mathrm{hr}$ supplements), and artificially ventilated with $100 \% \mathrm{O}_{2}$ (50 cycles per minute; tidal volume, $3 \mathrm{ml}$ ). Small adjustments in minute ventilation were made as necessary to maintain end-tidal $\mathrm{CO}_{2}$ between 4 and $5 \%$. Throughout most of the experiment, colonic temperature was maintained at $37.5^{\circ} \mathrm{C}$ with a heating plate beneath the animal and a heat lamp. To provide a natural stimulus for the activation of the sympathetic nerve discharge to BAT, body temperature was lowered once in each animal by turning off the heat sources and placing dry ice in contact with the metal heating plate beneath the animal for $\sim 5 \mathrm{~min}$. This caused body temperature to fall from 37.5 to $34-35^{\circ} \mathrm{C}$ within $10 \mathrm{~min}$, at which time the heat sources were turned on and body temperature returned to $37.5^{\circ} \mathrm{C}$.

Postganglionic sympathetic nerve activity to BAT was recorded from the central cut end of a small nerve bundle dissected from the ventral surface of the right interscapular BAT (IBAT) after the fat pad was divided along the midline and reflected laterally. Nerve activity was recorded with bipolar hook electrodes in a monopolar configuration, filtered $(1-300 \mathrm{~Hz})$ and amplified (50,000 times) with a Cyberamp 380 (Axon Instruments, Foster City, CA), and digitized and recorded (Neurodata, Woods Hole, MA) on videocassette-recorder tape along with the arterial pressure and stimulus trigger pulses.

A stimulating electrode and, subsequently, a microinjection pipette (tip outside diameter, $20 \mu \mathrm{m}$ ) were positioned stereotaxically in the RPa after a partial occipital craniotomy and reflection of the atlanto-occipital membrane. Relative to the calamus scriptorius, the coordinates for the RPa were as follows: anteroposterior, $3.0 \mathrm{~mm}$; mediolateral, $0.0 \mathrm{~mm}$; and dorsoventral, $-2.7 \mathrm{~mm}$. At the end of each experiment, the microinjection pipette was retracted vertically from the $\mathrm{RPa}$, refilled with a $1 \%$ solution of fast green dye, and lowered to the site of microinjection (and stimulation). Dye was electrophoretically deposited $(15 \mu \mathrm{A}$ anodal direct current for 15 min). After perfusion and histological processing, the locations of the microinjection sites in the RPa were plotted on camera lucida drawings of sections through the rostral medulla (Paxinos and Watson, 1986). Stimuli, applied through a monopolar tungsten microelectrode $(30 \mu \mathrm{m}$ exposed tip), consisted of twin pulses of $1 \mathrm{msec}$ duration, $6 \mathrm{msec}$ interpulse interval, 5-150 $\mu \mathrm{A}$, delivered at $0.4 \mathrm{~Hz}$.

During the experimental protocol, arterial pressure, heart rate, and BAT SNA were recorded (1) during an initial control period with body temperature maintained at $\sim 37.5^{\circ} \mathrm{C}$, (2) during a reduction in body temperature, including responses to electrical stimuli applied to $\mathrm{RPa}$, (3) during a second control period $30 \mathrm{~min}$ after the return to normal body temperature, and (4) during a microinjection of vehicle (saline) and of the $\mathrm{GABA}_{\mathrm{A}}$ antagonist, bicuculline methiodide $(60 \mathrm{nl}, 500 \mu \mathrm{M})$, into RPa. No differences were observed between the parameters recorded during the first and second control periods, and no responses were ever noted to microinjection of saline into RPa.

After digitization at $1 \mathrm{kHz}$, arterial pressure and BAT SNA signals were analyzed with software written in the ASYST (Keithley Instruments, Cleveland, $\mathrm{OH}$ ) programming environment. The amplitude of the BAT SNA and the mean frequency of the bursts in nerve activity were derived from autospectral analysis. For each experimental condition, an average autospectrum of a $20.5 \mathrm{sec}$ period of sympathetic nerve activity to BAT was obtained by dividing the data record into nine $4.1 \mathrm{sec}$ segments with a $50 \%$ overlap. The power value of the average autospectrum at each frequency point was computed as the mean value of the powers at that frequency in the individual autospectra of these nine segments. The amplitude of the sympathetic nerve activity to BAT was taken as the root mean square value of the total power in the $1-10 \mathrm{~Hz}$ band of the averaged autospectrum and is expressed in the text simply as "units." The mean burst frequency of BAT SNA was obtained as the weighted mean frequency within the $2 \mathrm{~Hz}$ interval containing the greatest power. Parameters defining the inverse relationship between body temperature and BAT SNA were obtained by measuring BAT SNA amplitude at several levels of body temperature as the temperature was lowered during the hypothermic portion of the protocol described above. These paired data points were fit to a "logistic" equation (Kent et al., 1972) to determine the gain of the relationship (slope of the linear portion of the curve) and the operating (set) point of the relationship (midpoint of the linear portion of the curve).

Ganglion cell counting. To compare the relative number and size of ganglion cells contributing axons to the sympathetic postganglionic nerves innervating the interscapular BAT in animals raised at 18 and $30^{\circ} \mathrm{C}$, we used the approach of Vera et al. (1997), injecting the retrograde tracer, fast blue, into the right interscapular fat pad. In each animal, eight fast blue injections $(1 \mu \mathrm{l}$ of a $2 \%$ solution) were made in a two-by-four grid: two rows ( 1 and $3 \mathrm{~mm}$ lateral to the vertebral processes) of four injections each (beginning at the rostral edge of the fat pad and separated by $2.0 \mathrm{~mm}$ ). After survival times of $10-12 \mathrm{~d}$, animals were anesthetized with $75 \mathrm{mg} / \mathrm{kg}$ sodium pentobarbital and perfused transcardially with $50 \mathrm{ml}$ of saline, followed by $500 \mathrm{ml}$ of $4 \%$ paraformaldehyde. The right sympathetic chain ganglia were removed from the superior cervical to the T5 level and placed in fixative for $1 \mathrm{hr}$. Individual ganglia were then sectioned at $50 \mu \mathrm{m}$ on a freezing microtome, mounted in gelatin-coated slides, air-dried, and examined under a fluorescent microscope. The number of fluorescent cell profiles in each section was counted, and the total number of retrogradely labeled cells in each ganglion in each animal was determined. Correction factors were not applied to these counts because (1) the diameters of the ganglion cells were less than half of the section thickness, (2) the sizes of the ganglion cells did not differ between the two groups of animals, and (3) identical procedures were followed for preparing the tissue in both animal groups. To obtain an estimate of the diameters of the ganglion cells in animals reared at 18 and $30^{\circ} \mathrm{C}$, computerized images of six fluorescent cell profiles were traced from sections of the middle cervical ganglia from each of five animals at each rearing temperature. The area of each cell profile was computed, as was a corresponding cell diameter, assuming that the cell was spherical. A mean cell diameter was determined for each animal, and these values were used to assess differences in ganglion cell size attributable to rearing temperature.

Analysis of BAT catecholamines. For norepinephrine (NE) analysis, interscapular BAT was weighed and homogenized in iced $0.2 \mathrm{~N}$ perchloric acid. After addition of the internal standard, dihydroxybenzylamine (Sigma, St. Louis, MO), catecholamines were isolated from the perchloric acid extract by adsorption onto alumina (Woelm neutral, ICN Nutritional Biochemicals) in the presence of $2 \mathrm{M}$ Tris (hydroxymethyl)-aminomethane buffer, pH 8.7 (Sigma), containing 2\% EDTA. Catecholamines were eluted from the alumina with $0.2 \mathrm{~N}$ perchloric acid. Analysis of BAT catecholamines in the alumina eluates was performed using the method of Eriksson and Persson (1982).

Data analysis. Data are displayed as means $\pm \mathrm{SE}$, unless otherwise noted. Statistical ANOVAs and covariance were performed using Data Desk 5.0 statistical software (Data Description, Ithaca, NY). In comparisons of NE content between groups before weaning, the ANOVA model included litter as an additional variable in a nested analysis. Post hoc, pair-wise comparisons after ANOVA used Sheffé's test. Statistical differences were also assessed with Student's paired $t$ test, with $p<0.05$.

\section{RESULTS}

The initial resting mean arterial pressures and heart rates in the animals raised at $18^{\circ} \mathrm{C}$ were not different from those of the animals raised at $30^{\circ} \mathrm{C}$ (Table 1$)$. The mean body weight of the males raised at $18^{\circ} \mathrm{C}(583 \pm 25 \mathrm{gm}, n=11)$ was significantly greater $(p<0.05)$ than that of the males raised at $30^{\circ} \mathrm{C}(485 \pm 29 \mathrm{gm}, n=6)$, although the weights of the females did not differ between the two rearing temperatures $\left(18^{\circ} \mathrm{C}: 345 \pm 15 \mathrm{gm}, n=19 ; 30^{\circ} \mathrm{C}: 348 \pm 24 \mathrm{gm}, n=8\right)$.

\section{Effect of rearing temperature on BAT SNA responses to acute hypothermia}

At normal body temperature $\left(37-38^{\circ} \mathrm{C}\right)$, there was little or no activity on the sympathetic nerve to BAT in rats raised at either 18 or $30^{\circ} \mathrm{C}$ (Fig. $1 A, B$, left panels, BAT SNA traces). The mean levels of normothermic control BAT SNA were not different between 


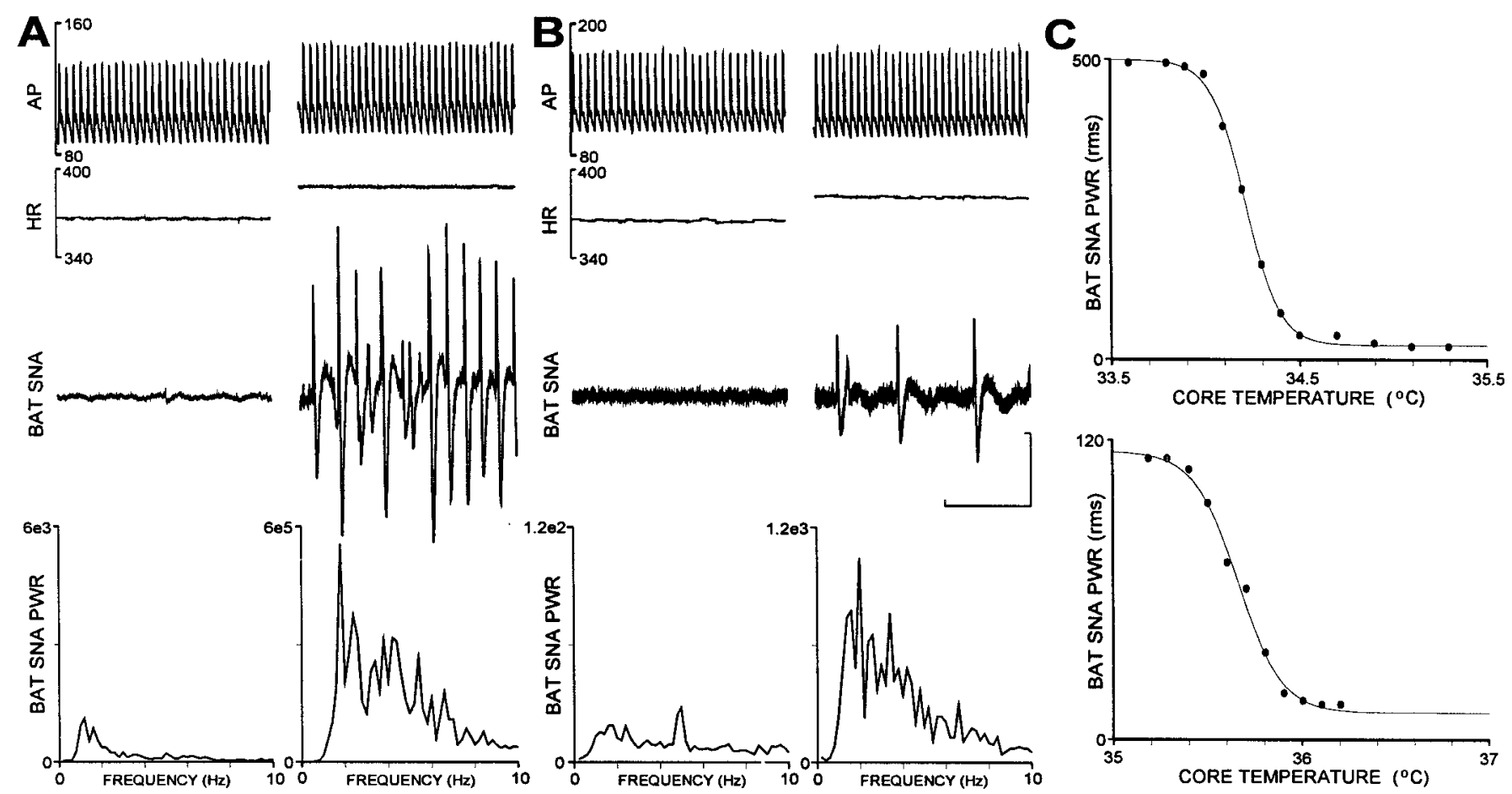

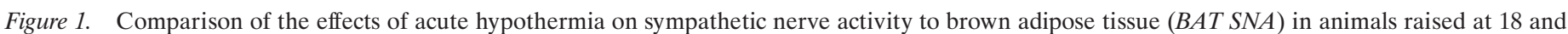

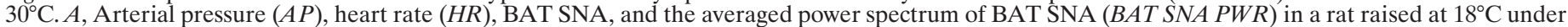

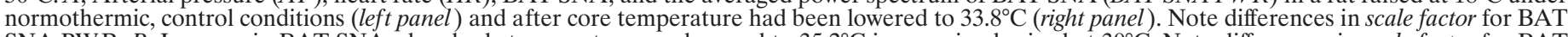

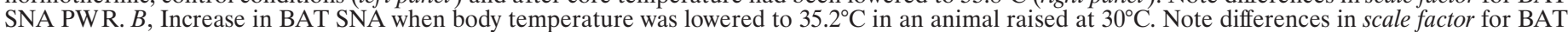

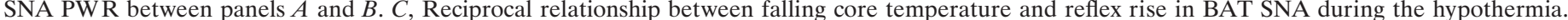

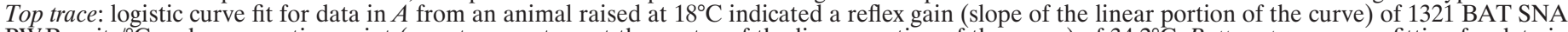

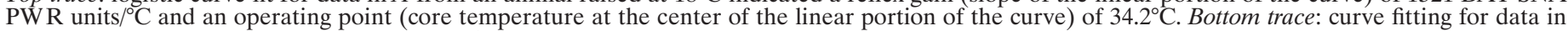

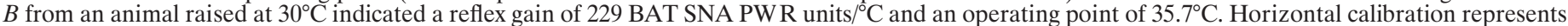
$1 \mathrm{sec}$ for the top three traces in $A$ and $B$, and the vertical calibration represents $50 \mu \mathrm{V}$ for the BAT SNA traces in panels $A$ and $B$.

animals raised at $18^{\circ} \mathrm{C}(25 \pm 2$ units $)$ and those raised at $30^{\circ} \mathrm{C}(30 \pm$ 4 units). As body temperature was lowered by ventral contact with a chilled surface and removal of external heating sources, BAT SNA increased in the form of isolated bursts (Fig. 1A,B, right panels, BAT SNA traces) indicating the synchronous discharge of sympathetic ganglion cell axons within the nerve bundle. The amplitude and frequency of the bursts in BAT SNA increased as body temperature fell, reaching a level of maximum total power that was sustained for a short time and then declined if body temperature was reduced further. Neither the threshold temperature for an increase in BAT SNA nor the body temperature at which the maximum increase in BAT SNA occurred was different between animals raised at $18^{\circ} \mathrm{C}$ (threshold, $35.6 \pm 0.2^{\circ} \mathrm{C}$; maximum BAT SNA, $34.7 \pm 0.2^{\circ} \mathrm{C}$ ) and those raised at $30^{\circ} \mathrm{C}$ (threshold, $35.5 \pm 0.2^{\circ} \mathrm{C}$; maximum BAT SNA, $34.6 \pm 0.3^{\circ} \mathrm{C}$ ). However, the maximum level of BAT SNA and the gain of the relationship between body temperature and BAT SNA were significantly greater in animals raised at $18^{\circ} \mathrm{C}$ than in those raised at $30^{\circ} \mathrm{C}$.

A representative example of the responses to acute hypothermia in a rat raised at $18^{\circ} \mathrm{C}$ is shown in Figure 1. The BAT SNA amplitude increased from 20 units at body temperatures $>34.9^{\circ} \mathrm{C}$ (Fig. 1A, left panel, BAT SNA PWR spectrum) to 471 units at a body temperature of $33.9^{\circ} \mathrm{C}$ (Fig. $1 A$, right panel). Fitting the body temperature measurements and the corresponding BAT SNA amplitudes to a logistic function (Kent et al., 1972) yielded a reflex gain of 1321 units $/{ }^{\circ} \mathrm{C}$ of BAT SNA and an operating point temperature of $34.2^{\circ} \mathrm{C}$ (Fig. $1 C$, top trace). In contrast, the amplitude of the BAT SNA in a rat raised at $30^{\circ} \mathrm{C}$ increased from 15 units at body temperatures $>36.0^{\circ} \mathrm{C}$ (Fig. $1 B$, left panel, BAT SNA PWR spectrum) to a maximum of 108 units at a body temperature of $35.4^{\circ} \mathrm{C}$ (Fig. $1 B$, right panel). This response had a reflex gain of 229 units of BAT SNA $/{ }^{\circ} \mathrm{C}$ and an operating point temperature of $35.7^{\circ} \mathrm{C}$ (Fig. $1 C$, bottom trace).
In the rats raised at $18^{\circ} \mathrm{C}$, the mean maximum level of BAT SNA occurring during the acute hypothermic stimulus was $365 \pm 54$ units, representing an increase of $353 \pm 54$ units $(1331 \pm 180 \%$ of control), which was significantly $(p<0.01)$ greater than the mean maximum level of BAT SNA (197 \pm 32 units) achieved in animals raised at $30^{\circ} \mathrm{C}$, representing an increase of $165 \pm 28$ units $(520 \pm$ $62 \%$ of control). The mean gain of the relationship between falling body temperature and increased BAT SNA was $568 \pm 95$ units/ $/{ }^{\circ} \mathrm{C}$ in the rats raised at $18^{\circ} \mathrm{C}$, which was significantly $(p<0.005)$ greater than that in the rats raised at $30^{\circ} \mathrm{C}\left(196 \pm 30 \mathrm{units} /{ }^{\circ} \mathrm{C}\right)$. The mean operating point temperatures were not different between rats reared at $18^{\circ} \mathrm{C}\left(35.1 \pm 0.2^{\circ} \mathrm{C}\right)$ and those reared at $30^{\circ} \mathrm{C}(35.1 \pm$ $\left.0.3^{\circ} \mathrm{C}\right)$. Mean arterial pressure and heart rate were also increased in both groups of animals during the hypothermic response (Fig. $1 A, B$, top traces), although the peak increases in mean arterial pressure and heart rate were not different between the rats raised at $18^{\circ} \mathrm{C}$ and those raised at $30^{\circ} \mathrm{C}$ (Table 1 ).

\section{Effect of rearing temperature on BAT SNA responses to disinhibition of RPa neurons}

A second stimulus that increases BAT SNA and thermogenesis is disinhibition of neurons in the rostral RPa (Morrison et al., 1999). This site may contain sympathetic premotor neurons providing an excitatory input to the spinal sympathetic preganglionic neurons for BAT, and reduced inhibition of RPa neurons may underlie the increase in BAT thermogenesis in response to a fall in body temperature (Morrison, 1999; Morrison et al., 1999). To determine whether exposure to a lowered environmental temperature in the early postnatal period would alter the BAT SNA response to activation of RPa neurons, we recorded the BAT SNA response to the blockade of local $\mathrm{GABA}_{\mathrm{A}}$ receptors in $\mathrm{RPa}$ with microinjections $(60 \mathrm{nl})$ of bicuculline $(500 \mu \mathrm{M})$.

Disinhibition of raphe pallidus neurons produced rapid and large 

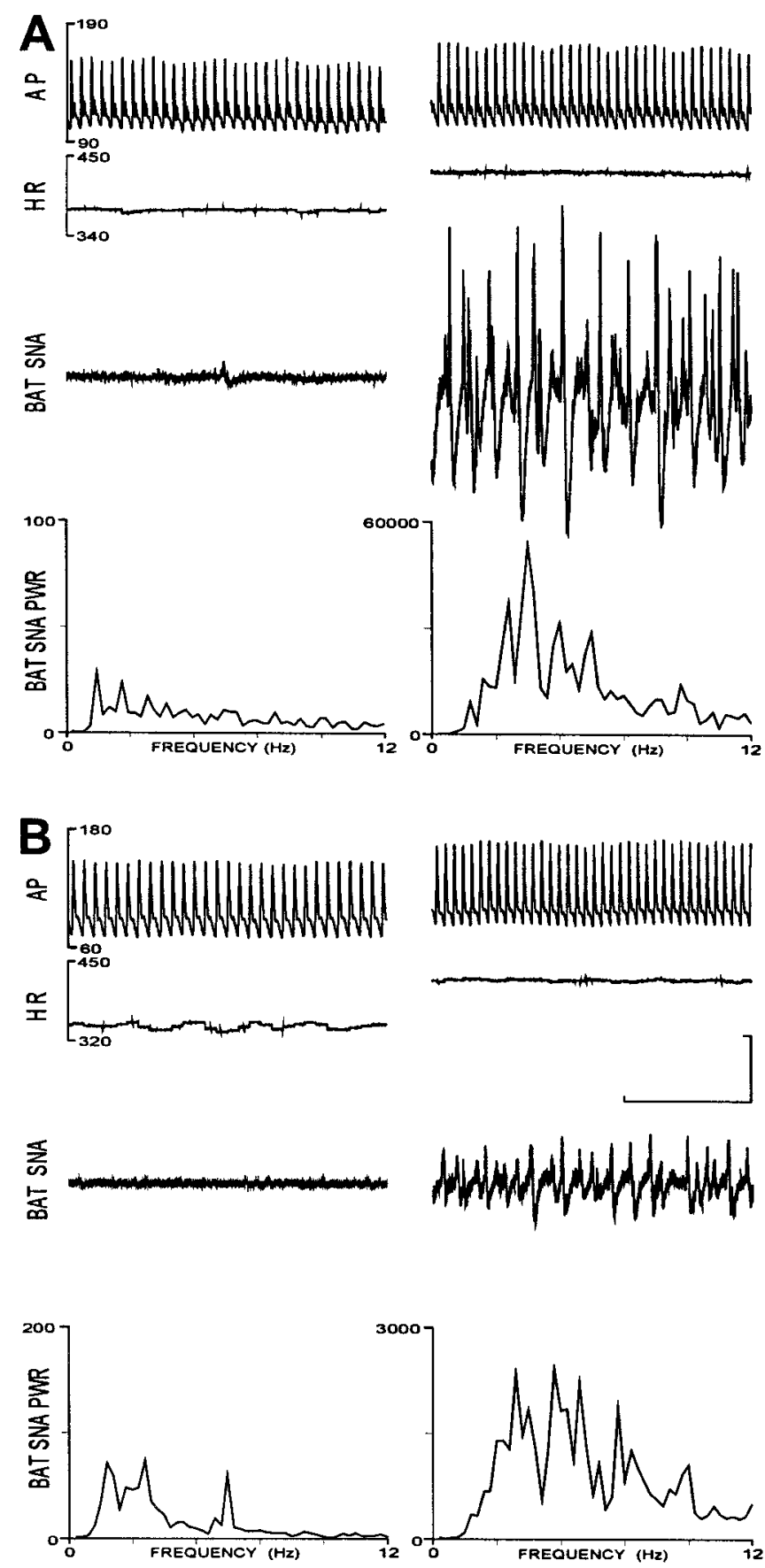

Figure 2. Comparison of the effects of disinhibition of raphe pallidus $(R P a)$ neurons on the sympathetic nerve activity to brown adipose tissue $(B A T S N A)$ in animals raised at 18 and $30^{\circ} \mathrm{C}$. $A$, Arterial pressure $(A P)$, heart rate $(H R)$, BAT SNA, and the averaged power spectrum of BAT SNA $(B A T S N A P W R)$ in a rat raised at $18^{\circ} \mathrm{C}$, under normothermic, control conditions (left) and $6 \mathrm{~min}$ after bicuculline was microinjected (60 $\mathrm{nl}, 500$ $\mu \mathrm{M}$ ) into the RPa (right). Note differences in the scale for BAT SNA PWR. $B$, Same traces as in $A$ in an animal raised at $30^{\circ} \mathrm{C}$ under normothermic, control conditions (right) and $7 \mathrm{~min}$ after a bicuculline microinjection into $\mathrm{RPa}$ (left). Note differences in scale factor for BAT SNA PWR between $A$ and $B$. Horizontal calibration represents $1 \mathrm{sec}$ for the top three traces in $A$ and $B$, and vertical calibration represents $50 \mu \mathrm{V}$ for the BAT SNA traces in $A$ and $B$.

increases in the sympathetic outflow to BAT in both groups of animals. In the example in Figure $2 A$ from an animal raised at $18^{\circ} \mathrm{C}$, the control level of BAT SNA (18 units) was increased to a maximum of 755 units (4194\% of control) at 6 min after microinjection of bicuculline into RPa. BAT SNA was increased in a similar manner by disinhibition of $\mathrm{RPa}$ neurons in the animal

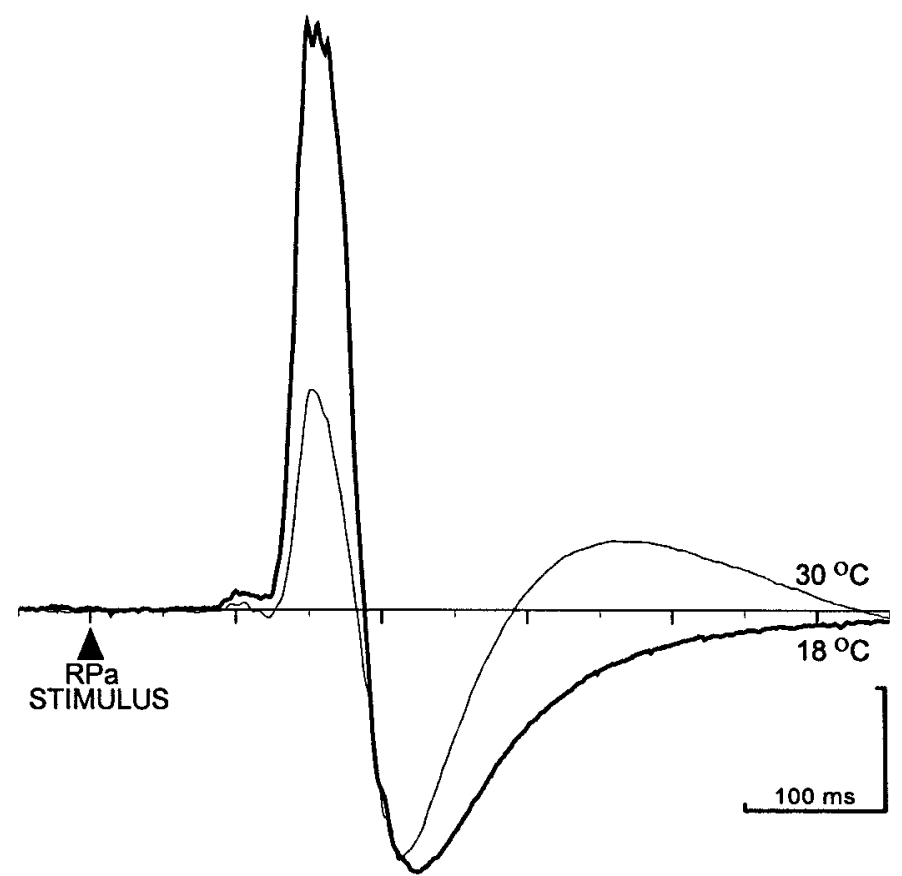

Figure 3. Comparison of averaged excitatory potentials evoked on a sympathetic nerve to BAT SNA by electrical stimulation in raphe pallidus $(R P a)$ in an animal raised at $18^{\circ} \mathrm{C}$ (heavy trace) and an animal raised at $30^{\circ} \mathrm{C}$ (light trace). Traces are peristimulus averages of the responses in BAT SNA to 10 stimuli consisting of paired pulses, $6 \mathrm{msec}$ interval, $100 \mu \mathrm{A}, 0.4 \mathrm{~Hz}$. Calibration: $50 \mu \mathrm{V} ; 100 \mathrm{msec}$.

raised at $30^{\circ} \mathrm{C}$ (Fig. $2 \mathrm{~B}$ ); however, the peak amplitude of BAT SNA (201 units; $773 \%$ of control) that was reached at $7 \mathrm{~min}$ after the bicuculline microinjection was markedly less than that in the animal raised at $18^{\circ} \mathrm{C}$

Microinjection of bicuculline into RPa evoked mean maximum levels of BAT SNA that were significantly $(p<0.005)$ higher in animals raised at $18^{\circ} \mathrm{C}(706 \pm 103$ units $)$ than those in the rats raised at $30^{\circ} \mathrm{C}$ (352 \pm 84 units). From control levels that were not different between groups, disinhibition of raphe pallidus neurons evoked increases in BAT SNA of $682 \pm 101$ units $(2820 \pm 294 \%$ of control) in animals raised at $18^{\circ} \mathrm{C}$, which were significantly greater $(p<0.05)$ than the $317 \pm 78$ units $(1746 \pm 545 \%$ of control $)$ increase in animals raised at $30^{\circ} \mathrm{C}$. Bicuculline microinjection into $\mathrm{RPa}$ also increased the mean arterial pressure and heart rate (Fig. $2 A, B)$, although the peak increases were not different between the two groups of rats (Table 1).

\section{Effect of rearing temperature on BAT SNA responses to stimulation in RPa}

Electrical stimulation (twin pulses, 5-150 $\mu \mathrm{A}, 0.5 \mathrm{~Hz}$ ) in $\mathrm{RPa}$ evoked excitatory potentials in BAT SNA (Fig. 3) with significantly larger peak amplitudes and areas in the rats raised at $18^{\circ} \mathrm{C}$ than in those raised at $30^{\circ} \mathrm{C}$. In the example in Figure 3, the peak amplitude $(232 \mu \mathrm{V})$ and area $(7489 \mu \mathrm{V} \cdot \mathrm{msec})$ of the RPa stimulusevoked potential in BAT SNA were 3.0 and 3.2 times greater, respectively, in the animal raised at $18^{\circ} \mathrm{C}$ than those in the rat raised at $30^{\circ} \mathrm{C}(77 \mu \mathrm{V}$ and $2324 \mu \mathrm{V} \cdot \mathrm{msec})$. On average, the mean peak amplitude of the RPa stimulus-evoked potentials in BAT SNA in the rats raised at $18^{\circ} \mathrm{C}(204 \pm 31 \mu \mathrm{V})$ was 2.1 times greater $(p<$ $0.05)$ than that $(98 \pm 16 \mu \mathrm{V})$ in the rats raised at $30^{\circ} \mathrm{C}$. Similarly, the mean area of the potentials was 2.2 times greater $(p<0.05)$ in the rats raised at $18^{\circ} \mathrm{C}(6269 \pm 987 \mu \mathrm{V} \cdot \mathrm{msec})$ than that $(2833 \pm 412$ $\mu \mathrm{V} \cdot \mathrm{msec})$ in the rats raised at $30^{\circ} \mathrm{C}$. Differences in rearing temperature did not induce any differences in the mean onset latency $(124 \pm 1.7 \mathrm{msec})$, mean peak latency $(157 \pm 2.3 \mathrm{msec})$, or duration $(61 \pm 2.9 \mathrm{msec})$ of the RPa stimulus-evoked potentials. Neither the threshold stimulus intensity $(9 \pm 1.3 \mu \mathrm{A})$ nor the body temperature 

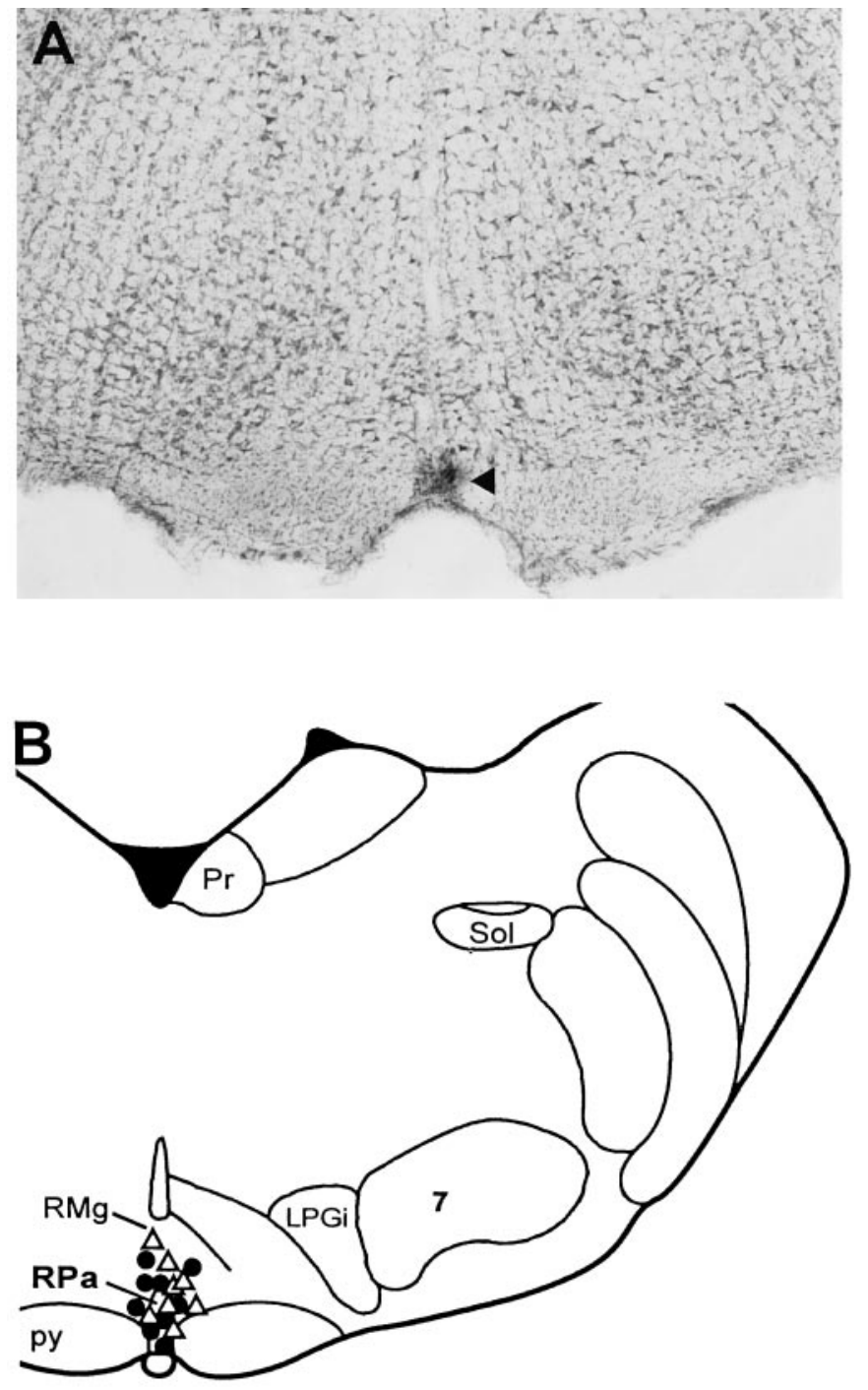

Figure 4. Locations of electrical stimulation and bicuculline microinjection sites in the rostral raphe pallidus $(R P a)$. $A$, Histological section through the rostral RPa containing fast green dye (arrow) deposited from the tip of a bicuculline microinjection pipette. $B$, Representative bicuculline microinjection sites from nine animals raised at $18^{\circ} \mathrm{C}(\mathcal{O})$ and seven animals raised at $30^{\circ} \mathrm{C}(\triangle)$, plotted on an atlas (Paxinos and Watson, 1986) drawing at interaural $-2.30 \mathrm{~mm}$. Microinjection sites in remaining animals were omitted for clarity. $P r$, prepositus hypoglossal nulceus; $R M g$, nucleus raphe magnus; Sol, nucleus of the solitary tract; $L P G i$, lateral paragigantocellular nucleus; 7 , facial nucleus; $p y$, pyramidal tract.

at which the stimulations were performed $\left(34.3 \pm 0.3^{\circ} \mathrm{C}\right)$ was different between the two groups of animals.

Representative bicuculline microinjection and electrical stimulation sites in RPa are shown in Figure 4. They were located in the rostral raphe pallidus and the overlying raphe magnus at the level of the caudal portion of the facial nucleus. There were no differences in the locations of the bicuculline microinjection sites or the electrical stimulation sites between animals raised at $18^{\circ} \mathrm{C}$ and those raised at $30^{\circ} \mathrm{C}$. The locations of these microinjections correspond to the raphe region within which bicuculline evokes a maximal increase in BAT SNA and in which neuronal c-fos expression is induced during acute cold exposure (Morrison et al., 1999).

\section{Effect of rearing temperature on NE levels in IBAT}

The impact of exposure to 18 and $30^{\circ} \mathrm{C}$ for the first 2 months of life on body weight, IBAT weight, and IBAT NE levels in 4-month-old male and female rats is presented in Table 2. In both male and female animals, body weights and IBAT weights were greater in the rats housed at $18^{\circ} \mathrm{C}$ than in those reared at $30^{\circ} \mathrm{C}$; however, the increase in IBAT weight was proportional to the gain in body weight in the $18^{\circ} \mathrm{C}$-reared animals. The NE levels in IBAT were elevated (both as nanograms per tissue and as nanograms per gram of tissue) in the rats raised in the colder environment. In contrast, cardiac NE levels (nanograms per gram of tissue) were either the same (males) or lower (females) in animals reared at $18^{\circ} \mathrm{C}$ versus those reared at $30^{\circ} \mathrm{C}$. Thus, exposure to a cold environment (18 vs $30^{\circ} \mathrm{C}$ ) for the first $60 \mathrm{~d}$ of life results in greater NE levels in BAT but not in heart, a difference that persisted for at least 2 months after relocation of both $18^{\circ} \mathrm{C}$-reared and $30^{\circ} \mathrm{C}$-reared animals to housing at a common temperature.

\section{Effect of rearing temperature on number of sympathetic ganglion cells innervating IBAT}

To determine whether the enhanced BAT SNA responses and the elevated IBAT NE levels in rats raised at $18^{\circ} \mathrm{C}$ might reflect a neuroanatomic alteration resulting from rearing temperature, we compared the number and size of sympathetic ganglion cells retrogradely labeled after fast blue injections into the IBAT in $18^{\circ} \mathrm{C}$ reared and $30^{\circ} \mathrm{C}$-reared rats. Figure 5 illustrates the greater number of ganglion cells innervating IBAT found in animals raised at $18^{\circ} \mathrm{C}$ in comparison to animals raised at $30^{\circ} \mathrm{C}$. The results derived from counting ganglion cells containing fast blue fluorescence are presented in Table 3. Injection of fast blue into IBAT labeled the greatest number of ganglion cells in the middle cervical-stellate ganglia, with decreasing numbers in the first four thoracic ganglia ipsilateral to the IBAT that was injected (Table 3). The mean diameter of middle cervical ganglion cells innervating BAT in animals $(n=5)$ reared at $18^{\circ} \mathrm{C}$ was $25 \pm 1.8 \mu \mathrm{m}$, which was not different from that in animals $(n=5)$ reared at $30^{\circ} \mathrm{C}(24 \pm 1.5 \mu \mathrm{m})$. The total number of ganglion cells labeled by fast blue injection into IBAT, as well as the number in the middle cervical-stellate ganglia and in the first thoracic ganglion, was significantly greater in the rats reared at $18^{\circ} \mathrm{C}$ than in those reared at $30^{\circ} \mathrm{C}$ (Table 3 ). The total number of ganglion cells retrogradely labeled from IBAT was $72 \%$ greater in animals reared at $18^{\circ} \mathrm{C}$ than in those reared at $30^{\circ} \mathrm{C}$, primarily because of populations of retrogradely labeled cells in the middle cervical-stellate ganglia that were $73 \%$ greater and in the first thoracic ganglion that were $63 \%$ greater. These data are consistent with the size of the differences noted above in BAT SNA response amplitudes and in IBAT NE levels and suggest that sympathetic postganglionic nerve bundles to BAT in $18^{\circ} \mathrm{C}$-reared animals contained a greater number of axons than those in $30^{\circ} \mathrm{C}$ reared rats.

\section{DISCUSSION}

The principal findings of this study are that early postnatal exposure to a cold $\left(18^{\circ} \mathrm{C}\right)$ environment induces a permanent enhancement of the responses to thermogenic stimuli in the sympathetic outflow to BAT and that a cold-induced hyperplasia within the sympathetic pathway to BAT may contribute to the exaggerated sympathetic responses in cold-reared animals. These data provide evidence that exposure during early postnatal life to an environment that activates BAT thermogenesis can produce a sustained change in the neural regulation of this thermoregulatory system.

The increased number of sympathetic ganglion cells innervating $\mathrm{BAT}$ in animals reared at $18^{\circ} \mathrm{C}$ is likely to be a consequence of an activity-induced reduction in the apoptotic processes that occur during this period (Aguayo et al., 1976; Wright et al., 1983; Smet et al., 1986; Messina et al., 1996; Tafreshi et al., 1998), a proposal supported by the finding that neonatal rats housed under similar conditions show heightened indices of sympathetic nerve activity to BAT by the second week of neonatal life (Bertin et al., 1990). Moreover, although norepinephrine levels in BAT begin to diverge in 18 - and $30^{\circ} \mathrm{C}$-reared rats after the first week of life (Bertin et al., 1990) (J. B. Young, unpublished observations), gene expression for nerve growth factor and neurotrophin-3 in BAT does not differ as a function of rearing temperature from birth through weaning (J. B. Young, N. Boufath, and J. Weiss, unpublished observations). Additionally, in the present study, we found that ganglion cell sizes 
Table 2. Effect of rearing temperature on body, IBAT, and cardiac weights and on IBAT and cardiac norepinephrine content

\begin{tabular}{|c|c|c|c|c|c|c|c|c|c|}
\hline & \multirow{2}{*}{$\begin{array}{l}\text { Body } \\
\text { weight } \\
\text { (gm) }\end{array}$} & \multicolumn{2}{|c|}{ IBAT weight } & \multicolumn{2}{|l|}{ IBAT NE } & \multicolumn{2}{|c|}{ Cardiac weight } & \multicolumn{2}{|l|}{ Cardiac NE } \\
\hline & & $\mathrm{mg}$ & $\% \mathrm{BW}$ & ng & $\mathrm{ng} / \mathrm{gm}$ & $\mathrm{mg}$ & $\% \mathrm{BW}$ & ng & $\mathrm{ng} / \mathrm{gm}$ \\
\hline \multicolumn{10}{|l|}{ Male } \\
\hline $18^{\circ} \mathrm{C}(n=24)$ & $546 \pm 8^{*}$ & $573 \pm 27^{* *}$ & $0.105 \pm 0.004$ & $721 \pm 30^{*}$ & $1286 \pm 52 *$ & $1328 \pm 17^{*}$ & $0.244 \pm .003$ & $601 \pm 27^{* *}$ & $450 \pm 19$ \\
\hline $30^{\circ} \mathrm{C}(n=24)$ & $466 \pm 7$ & $490 \pm 20$ & $0.105 \pm 0.004$ & $393 \pm 16$ & $842 \pm 54$ & $1103 \pm 22$ & $0.237 \pm .003$ & $478 \pm 29$ & $433 \pm 24$ \\
\hline \multicolumn{10}{|l|}{ Female } \\
\hline $18^{\circ} \mathrm{C}(n=16)$ & $336 \pm 5^{* *}$ & $373 \pm 22^{* *}$ & $0.111 \pm 0.006$ & $862 \pm 35^{*}$ & $2436 \pm 173^{*}$ & $1016 \pm 17^{*}$ & $0.303 \pm .006^{* *}$ & $849 \pm 56$ & $832 \pm 49 * *$ \\
\hline $30^{\circ} \mathrm{C}(n=23)$ & $311 \pm 5$ & $319 \pm 14$ & $0.103 \pm 0.004$ & $524 \pm 16$ & $1695 \pm 72$ & $886 \pm 13$ & $0.286 \pm .004$ & $890 \pm 31$ & $1008 \pm 36$ \\
\hline
\end{tabular}

$I B A T$, Interscapular brown adipose tissue; $N E$, norepinephrine; $B W$, body weight.

$*, * *$ Significant difference $(p<0.001)^{*}$ and $(p<0.05)^{* *}$ between $18^{\circ} \mathrm{C}$ - and $30^{\circ} \mathrm{C}$-reared rats.
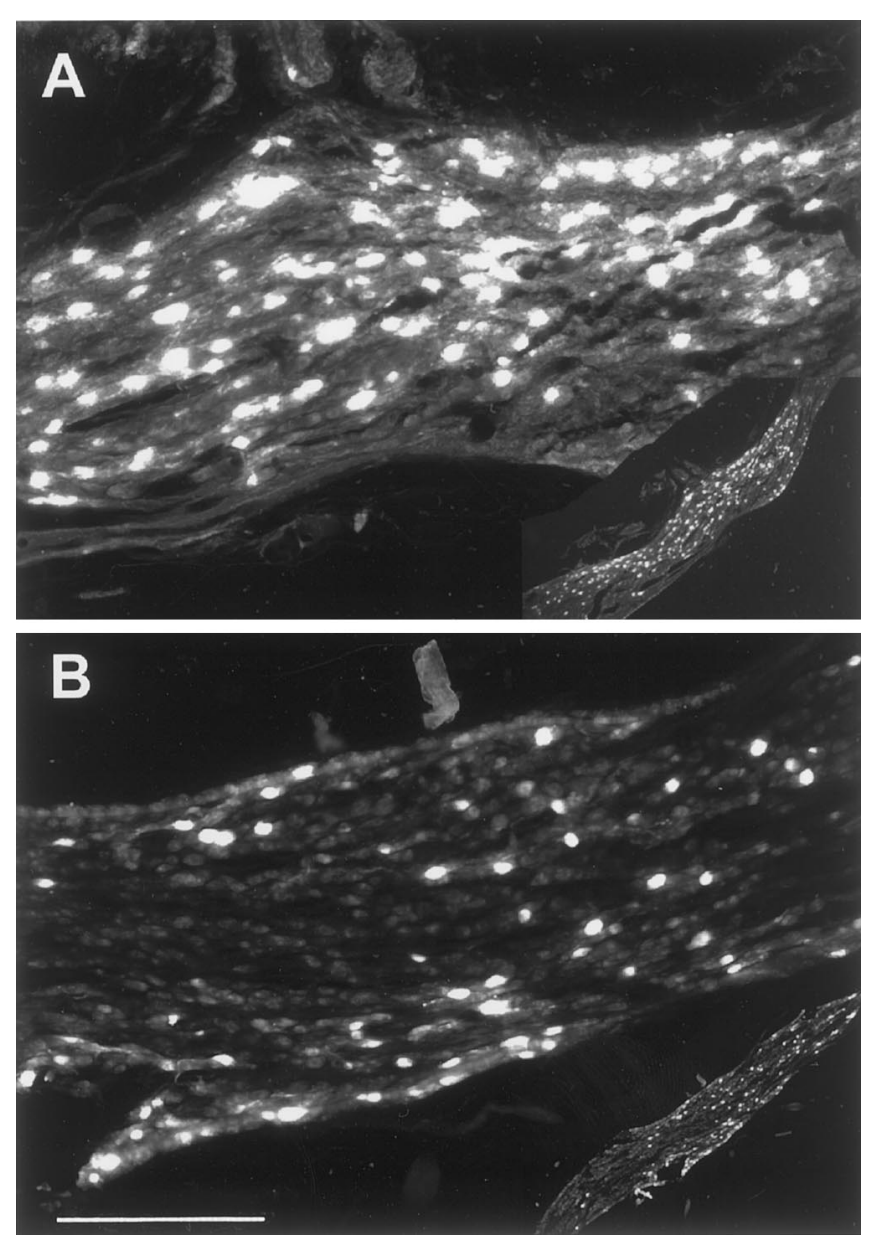

Figure 5. Comparison of the retrograde labeling of middle cervical ganglion cells in an animal raised at $18^{\circ} \mathrm{C}(A)$ and an animal raised at $30^{\circ} \mathrm{C}(B)$ after fast blue dye deposits in the ipsilateral IBAT. Histological sections have been illuminated to reveal fast blue fluorescence in ganglion cells innervating IBAT. Insets at bottom right show low-power images of these sections. The section from the middle cervical ganglion of the animal raised at $18^{\circ} \mathrm{C}$ contained 303 retrogradely labeled neurons $(A)$, whereas that from the same site in an animal raised at $30^{\circ} \mathrm{C}$ contained 117 neurons with fast blue fluorescence $(B)$. Scale bar: high-power images, $300 \mu \mathrm{m}$; low-power images, $2400 \mu \mathrm{m}$.

were not different between rats raised at 18 and $30^{\circ} \mathrm{C}$. Also arguing against a potential role for BAT-derived NGF in the augmented number of sympathetic ganglion cells innervating BAT in $18^{\circ} \mathrm{C}$ reared rats is the demonstration that BAT NGF production declined when adult rats were exposed to cold temperatures and that addition of norepinephrine to cultures of BAT cells reduced their NGF production (Nisoli et al., 1996). Together these observations implicate presynaptic signaling rather than target-derived factors in the augmented ganglion cell numbers in rats raised at $18^{\circ} \mathrm{C}$. We cannot rule out, however, a role for possible cold-induced alterations in ganglion cell function that may have influenced our observations, such as an increased ability to transport fast blue or a greater incidence of coupling between neurons.

Other CNS pathways exhibit a comparable developmental plasticity in which a modified perinatal environment produced by controlling a particular sensory stimulus results in a sustained alteration in an associated neuronal system performance. Kuno and colleagues (Kuno, 1956) determined that the sweating response to body heating was influenced by the environment in which an individual had lived for the first 2 years of life. Because the density of sweat glands in adult skin did not vary by race or by location of rearing, Kuno concluded that the observed differences in rate of perspiration derived from developmental alterations in the neural regulation of this response. Ventilatory responses to hypoxemia are greatly attenuated in adult rats in which the peripheral chemoreceptor reflex was suppressed during the first month of life by living in a hyperoxic environment (Ling et al., 1996, 1997). Litter size and neonatal handling are additional factors in perinatal life that can alter development of the neural system involved in homeostasis (Plagemann et al., 1999; Young, 2000). The sympathetic nervous system is composed of multiple, functionally specific subunits (Janig and McLachlan, 1992), each of which may be susceptible to the developmental influences of exposure to a different set of environmental conditions. Extending this model of neuronal plasticity for the sympathetic nervous system, sympathetic function in the adult would reflect the net result of the host of environmental factors to which the individual was exposed during early life.

Neurons in the preoptic region of the hypothalamus play a central role in the integration of information on body and environmental temperature and in the elaboration of autonomic and behavioral responses required to maintain a constant body temperature (Boulant and Dean, 1986; Gordon and Heath, 1986). Although activation of BAT thermogenesis in the rat is a major component of the response to a cold environment, the central pathways mediating increases in BAT SNA have not been determined. Recently, the $\mathrm{RPa}$ has been identified as a potential site of the sympathetic premotor neurons providing the principal excitatory input to spinal sympathetic preganglionic neurons controlling BAT thermogenesis (Morrison et al., 1999). The finding that the level of BAT SNA is very low under control, normothermic conditions, but is dramatically increased by disinhibition of RPa neurons (Morrison et al., 1999) (Fig. 2), is consistent with the existence of a potent, tonic, GABA-mediated inhibition of the RPa neurons controlling BAT thermogenesis that is relieved during periods when BAT thermogenesis is stimulated. These results lead to the hypothesis that the reduction in environmental temperature experienced by rats reared at $18^{\circ} \mathrm{C}$ stimulated an elevated level of activity in their BAT thermogenic pathway, including cold-sensitive neurons in the hypothalamus (Boulant and Dean, 1986) and BAT sympathetic premotor neurons in the $\mathrm{RPa}$, which, in turn, induced an increase in the number of ganglion cells innervating BAT and resulted in the enhanced responses recorded in their BAT SNA. Although our data indicate that RPa neurons can influence those components of 
Table 3. Effect of rearing temperature on numbers of sympathetic ganglion cells innervating interscapular brown adipose tissue

\begin{tabular}{llllll} 
Rearing temperature & Total per rat & $\begin{array}{l}\text { Middle cervical } \\
\text { stellate }\end{array}$ & T1 & T2 & T3 \\
\hline $18^{\circ} \mathrm{C}(n=9)$ & $2659 \pm 318^{*}$ & $2000 \pm 303^{*}$ & $354 \pm 38^{* *}$ & $213 \pm 45$ & $88 \pm 24$ \\
$30^{\circ} \mathrm{C}(n=11)$ & $1545 \pm 111$ & $1154 \pm 74$ & $217 \pm 42$ & $151 \pm 30$ & $60 \pm 19$
\end{tabular}

Numbers are means \pm SEM of cells per ganglion retrogradely labeled from unilateral fast blue injections into right interscapular brown adipose tissue.

$*, * *$ Significant difference $(p<0.01)^{*}$ and $(p<0.05)^{* *}$ between $18^{\circ} \mathrm{C}$ - and $30^{\circ} \mathrm{C}$-reared rats.

the BAT thermogenic pathway that are enhanced in rats reared at $18^{\circ} \mathrm{C}$, we did not determine whether an increase in the responsiveness or the number of RPa neurons contributed to the increased amplitude of the responses recorded in rats reared at $18^{\circ} \mathrm{C}$. The finding that disinhibition of RPa neurons produced large increases in BAT SNA, but only small changes in the visceral vasoconstrictor outflow in the splanchnic nerve (Morrison, 1999), suggests that the sympathetic efferents regulated by RPa neuronal activity are those specifically involved in thermoregulation or metabolism. Thus, we would not expect responses evoked in cardiovascular sympathetic efferents to differ between rats reared at $18^{\circ} \mathrm{C}$ and those reared at $30^{\circ} \mathrm{C}$, although this was not tested in our study.

The close parallel between the relative amplitudes of the evoked increases in BAT SNA determined in the rats raised at $18^{\circ} \mathrm{C}$ and those raised at $30^{\circ} \mathrm{C}$ and the relative difference in the number of ganglion cells innervating IBAT between the $18^{\circ} \mathrm{C}$-reared animals and their $30^{\circ} \mathrm{C}$-reared counterparts suggests that the enhanced sympathetic responses in the cold-reared animals were mediated to a significant degree by the greater number of postganglionic axons in the nerves innervating BAT. Specifically, the maximal increase in BAT SNA activated by hypothermia, disinhibition of RPa neurons, and electrical stimulation of $\mathrm{RPa}$ was 85,100 , and $110 \%$ greater, respectively, in the $18^{\circ} \mathrm{C}$-reared rats than in the $30^{\circ} \mathrm{C}$ reared animals. The finding that these values are of the same order as both the $72 \%$ difference in the number of sympathetic ganglion cells retrogradely labeled from IBAT and the $83 \%$ difference in IBAT norepinephrine content in $18^{\circ} \mathrm{C}$ - versus $30^{\circ} \mathrm{C}$-reared animals suggests that the simplest explanation for the enhanced BAT sympathetic responses in the rats reared at $18^{\circ} \mathrm{C}$ is the greater number of postganglionic axons in the nerves innervating their BAT. A similar relationship between postganglionic sympathetic burst amplitude and the number of active preganglionic and postganglionic axons has been proposed, based on the sequential reduction in the heights of the spontaneous bursts in inferior cardiac postganglionic sympathetic discharge produced by sequential section of preganglionic rami to the stellate ganglion (Ninomiya et al., 1993). Although based on indirect evidence, this hypothesis is plausible if individual postganglionic axons do not discharge, to a significant degree, more than once during an individual sympathetic burst. Recordings of individual postganglionic muscle vasoconstrictor axons in awake human subjects indicate that, although such units can exhibit multiple discharges during a single sympathetic burst, these events are rare (Macefield and Wallin, 1999; Macefield et al., 1999). It was not determined in this study whether cold-rearing also induces a greater number of BAT sympathetic preganglionic neurons or their antecedent premotor neurons or whether the synaptic gain within the pathway leading to the excitation of ganglion cells innervating BAT is augmented.

In this study, we characterized two aspects of the inverse sigmoid relationship between core temperature and the amplitude of BAT SNA: (1) the threshold temperature at which BAT SNA began to increase and (2) the operating point temperature, determined as the midpoint on the linear portion of the curve. Our finding that both the mean threshold temperature $\left(35.5^{\circ} \mathrm{C}\right)$ and the mean operating point temperature $\left(35.1^{\circ} \mathrm{C}\right)$ were markedly less than the normal core temperature of the awake rat $\left(37.5^{\circ} \mathrm{C}\right)$ would suggest that the temperature regulatory mechanisms in these animals are suppressed by anesthesia. Chloralose, one component of the anesthesia used in these experiments, has been suggested to lower the threshold temperature and reduce the response dynamics of thermoregulation (Grewe et al., 1995). Additionally, our stimulus for producing an acute hypothermia involved ventral contact with a chilled surface, which would likely have activated cutaneous cold receptors before reducing core temperature. Thus, coupled with the effects of anesthesia, the potential for the networks controlling BAT SNA to be differentially sensitive to activation of cutaneous receptors versus stimulation of cold-sensitive neurons in the hypothalamus may have masked a developmentally induced difference in thermal sensitivity between rats reared at 18 and $30^{\circ} \mathrm{C}$.

Because animals raised at either 18 or $30^{\circ} \mathrm{C}$ had a similar range of temperatures from threshold to maximal BAT SNA responses, the greater gain of the relationship between core temperature and BAT SNA amplitude in the $18^{\circ} \mathrm{C}$-reared rats was strongly influenced by the enhanced maximal levels of BAT SNA that could be generated by $18^{\circ} \mathrm{C}$-reared rats in comparison to those reared at $30^{\circ} \mathrm{C}$. This developmental adaptation would allow cold-reared rats to achieve a greater maximal metabolic thermogenic response to cold stress more rapidly than their counterparts raised in a warmer environment.

\section{REFERENCES}

Aguayo AJ, Peyronnard JM, Terry LC, Romine JS, Bray GM (1976) Neonatal neuronal loss in rat superior cervical ganglia: retrograde effects on developing preganglionic axons and Schwann cells. J Neurocytol 5:137-155.

Bertin R, Mouroux I, De Marco F, Portet R (1990) Norepinephrine turnover in brown adipose tissue of young rats: effects of rearing temperature. Am J Physiol 259:R90-R96.

Boulant JA (1980) Hypothalamic control of thermoregulation. In: The handbook of the hypothalamus (Morgane PJ, Panksepp J, eds), pp 1-82. New York: Dekker.

Boulant JA, Dean JB (1986) Temperature receptors in the central nervous system. Annu Rev Physiol 48:639-654.

Brunjes PC, Frazier LL (1986) Maturation and plasticity in the olfactory system of vertebrates. Brain Res Rev 11:1-45.

Erickson JT, Mayer C, Jawa A, Ling L, Olson EB Jr, Vidruk EH, Mitchell GS, Katz DM (1998) Chemoafferent degeneration and carotid body hypoplasia following chronic hyperoxia in newborn rats. J Physiol (Lond) 509:519-526.

Eriksson BM, Persson BA (1982) Determination of catecholamines in rat heart tissue and plasma samples by liquid chromatography and electrochemical detection. J Chromatogr 228:143-154.

Foster DO (1984) Quantitative contribution of brown adipose tissue thermogenesis to overall metabolism. Can J Biochem Cell Biol 62:618-622.

Foster DO, Frydman ML (1979) Tissue distribution of cold-induced thermogenesis in conscious warm- or cold-acclimated rats reevaluated from changes in tissue blood flow: the dominant role of brown adipose tissue in the replacement of shivering by nonshivering thermogenesis. Can J Physiol Pharmacol 57:257-270.

Gordon CJ, Heath JE (1986) Integration and central processing in temperature regulation. Annu Rev Physiol 48:595-612.

Grewe W, Janig W, Kummel H (1995) Effects of hypothalamic thermal stimuli on sympathetic neurones innervating skin and skeletal muscle of the cat hindlimb. J Physiol (Lond) 488:139-152.

Hubel DH, Wiesel TN (1970) The period of susceptibility to the physiological effects of unilateral eye closure in kittens. J Physiol (Lond) 206:419-436.

Janig W, McLachlan EM (1992) Characteristics of function-specific pathways in the sympathetic nervous system. Trends Neurosci 15:475-481.

Kawate R, Talan MI, Engel BT (1994) Sympathetic nervous activity to brown adipose tissue increases in cold-tolerant mice. Physiol Behav 55:921-925.

Kent BB, Drane JW, Blumenstein B, Manning JW (1972) A mathematical model to assess changes in the baroreceptor reflex. Cardiology 57:295-310.

Kuno Y (1956) Human perspiration. Springfield, IL: Thomas.

LeBlanc J, Robinson D, Sharman DF, Tousignant P (1967) Cat- 
echolamines and short-term adaptation to cold in mice. Am J Physiol 213:1419-1422

Ling L, Olson Jr EB, Vidruk EH, Mitchell GS (1996) Attenuation of the hypoxic ventilatory response in adult rats following one month of perinatal hyperoxia. J Physiol (Lond) 495:561-571.

Ling L, Olson Jr EB, Vidruk EH, Mitchell GS (1997) Developmental plasticity of the hypoxic ventilatory response. Respir Physiol 110:261-268.

Macefield VG, Wallin BG (1999) Firing properties of single vasoconstrictor neurones in human subjects with high levels of muscle sympathetic activity. J Physiol (Lond) 516:293-301.

Macefield VG, Rundqvist B, Sverrisdottir YB, Wallin BG, Elam M (1999) Firing properties of single muscle vasoconstrictor neurons in the sympathoexcitation associated with congestive heart failure. Circulation 100:1708-1713.

Messina A, Jaworowski A, Bell C (1996) Detection of jun but not fos protein during developmental cell death in sympathetic neurons. J Comp Neurol 372:544-550.

Moore DR (1985) Postnatal development of the mammalian central auditory system and the neural consequences of auditory deprivation. Acta Otolaryngol [Suppl] 421:19-30.

Morrison SF (1999) RVLM and raphe differentially regulate sympathetic outflows to splanchnic and brown adipose tissue. Am J Physiol 276:R962-973.

Morrison SF, Young JB (1998) Developmental plasticity in sympathetic outflow: lowered neonatal temperature enhances sympathetic regulation of brown adipose tissue. Soc Neurosci Abstr 24:367.

Morrison SF, Sved AF, Passerin AM (1999) GABA-mediated inhibition of raphe pallidus neurons regulates sympathetic outflow to brown adipose tissue. Am J Physiol 276:R290-297.

Ninomiya I, Malpas SC, Matsukawa K, Shindo T, Akiyama T (1993) The amplitude of synchronized cardiac sympathetic nerve activity reflects the number of activated pre- and postganglionic fibers in anesthetized cats. J Auton Nerv Syst 45:139-147.
Nisoli E, Tonello C, Benarese M, Liberini P, Carruba M (1996) Expression of nerve growth factor in brown adipose tissue: implications for thermogenesis and obesity. Endocrinology 137:495-503.

Paxinos G, Watson C (1986) The rat brain in stereotaxic coordinates, Ed 2. Sydney, Australia: Academic.

Plagemann A, Harder T, Rake A, Melchior K, Rohde W, Dorner G (1999) Increased number of galanin neurons in the paraventricular hypothalamic nucleus of neonatally overfed weanling rats. Brain Res 818:160-163.

Smet P, Rush RA, Straznicky C (1986) The thoracic sympathetic neurons of the chick: normal development and the effects of nerve growth factor. Histol Histopathol 1:315-322.

Tafreshi AP, Zhou XF, Rush RA (1998) Endogenous nerve growth factor and neurotrophin-3 act simultaneously to ensure the survival of postnatal sympathetic neurons in vivo. Neuroscience 83:373-380.

Talan MI, Engel BT (1988) Habituation and dishabituation to repeated mild cold exposures in C57BL/6J mice. Physiol Behav 44:753-757.

Thoenen H (1995) Neurotrophins and neuronal plasticity. Science 270:593-598.

Vera PL, Haase EB, Schramm LP (1997) Origins of the sympathetic innervation of the cervical end of the uterus in the rat. Brain Res 747:140-143.

Woolsey TA, Durham D, Harris RM, Simons DJ, Valentino KL (1981) Somatosensory development. In: Development of perception. Psychobiological perspectives, Vol 1. Audition, somatic perception and the chemical senses (Aslin RN, Alberts JR, Peterson MR, eds), pp 259-292. New York: Academic.

Wright LL, Cunningham TJ, Smolen AJ (1983) Developmental neuron death in the rat superior cervical sympathetic ganglion: cell counts and ultrastructure. J Neurocytol 12:727-738.

Young JB (2000) Effects of neonatal handling on sympathoadrenal activity and body composition in adult male rats. Am J Physiol 279:1745-1752. 